\title{
Labor in Developing Economies
}





\section{A Publication of the \\ Institute of Industrial Relations \\ University of California}

\section{Labor}

in Developing

Economies

EDITED BY WALTER GALENSON

Berkeley and Los Angeles, 1963 UNIVERSITY OF CALIFORNIA PRESS 


\section{UNIVERSITY OF CALIFORNIA PRESS BERKELEY AND LOS ANGELES \\ CALIFORNIA \\ CAMBRIDGE UNIVERSITY PRESS \\ LONDON, ENGLAND \\ (C) 1962 BY}

THE REGENTS OF THE UNIVERSITY OF CALIFORNIA

SECOND PRINTING, 1963

LIBRARY OF CONGRESS CATALOG CARD NUMBER: 62-8491

MANUFACTURED IN THE UNITED STATES OF AMERICA 